Open Access

\title{
Experimental assessment of oxygen homeostasis during acute hemodilution: the integrated role of hemoglobin concentration and blood pressure
}

Tiffanie Kei ${ }^{1}$, Nikhil Mistry ${ }^{1,3}$, Albert K. Y. Tsuii, Elaine Liu ${ }^{1,2}$, Stephen Rogers ${ }^{4}$, Allan Doctor ${ }^{4}$, David F. Wilson ${ }^{5}$, Jean-Francois Desjardins ${ }^{2,6}$, Kim Connelly ${ }^{2,6}$, C. David Mazer ${ }^{1,2,3}$ and Gregory M. T. Hare ${ }^{1,2,3^{*}}$

\footnotetext{
*Correspondence: hareg@smh.ca ${ }^{1}$ Department of Anesthesia, St. Michael's Hospital, 30 Bond Street, Toronto, Ontario M5B 1W8, Canada 'Keenan Research Centre for Biomedical Science, Li Ka Shing Knowledge Institute, St. Michael's Hospital, 30 Bond Street, Toronto, Ontario M5B 1W8, Canada Full list of author information is available at the end of the article
}

\begin{abstract}
Background: Low hemoglobin concentration $(\mathrm{Hb})$ and low mean arterial blood pressure (MAP) impact outcomes in critically ill patients. We utilized an experimental model of "normotensive" vs. "hypotensive" acute hemodilutional anemia to test whether optimal tissue perfusion is dependent on both $\mathrm{Hb}$ and MAP during acute blood loss and fluid resuscitation, and to assess the value of direct measurements of the partial pressure of oxygen in tissue $\left(\mathrm{P}_{t} \mathrm{O}_{2}\right)$.

Methods: Twenty-nine anesthetized rats underwent $40 \%$ isovolemic hemodilution (1:1) (or sham-hemodilution control, $n=4)$ with either hydroxyethyl starch (HES) ( $n=14$, normotensive anemia) or saline ( $n=11$, hypotensive anemia) to reach a target $\mathrm{Hb}$ value near $70 \mathrm{~g} / \mathrm{L}$. The partial pressure of oxygen in the brain and skeletal muscle tissue $\left(\mathrm{P}_{\mathrm{t}} \mathrm{O}_{2}\right)$ were measured by phosphorescence quenching of oxygen using G4 Oxyphor. Mean arterial pressure (MAP), heart rate, temperature, arterial and venous co-oximetry, blood gases, and lactate were assessed at baseline and for 60 min after hemodilution. Cardiac output (CO) was measured at baseline and immediately after hemodilution. Data were analyzed by repeated measures two-way ANOVA.

Results: Following "normotensive" hemodilution with HES, Hb was reduced to $66 \pm$ $6 \mathrm{~g} / \mathrm{L}, \mathrm{CO}$ increased $(p<0.05)$, and MAP was maintained. These conditions resulted in a reduction in brain $\mathrm{P}_{\mathrm{t}} \mathrm{O}_{2}(22.1 \pm 5.6 \mathrm{mmHg}$ to $17.5 \pm 4.4 \mathrm{mmHg}, p<0.05)$, unchanged muscle $\mathrm{PO}_{2}$, and an increase in venous oxygen extraction. Following "hypotensive" hemodilution with saline, $\mathrm{Hb}$ was reduced to $79 \pm 5 \mathrm{~g} / \mathrm{L}$ and both $\mathrm{CO}$ and MAP were decreased $(P<0.05)$. These conditions resulted in a more severe reduction in brain $\mathrm{P}_{\mathrm{t}} \mathrm{O}_{2}\left(23.2 \pm 8.2\right.$ to $10.7 \pm 3.6 \mathrm{mmHg}(p<0.05)$, a reduction in muscle $\mathrm{P}_{\mathrm{t}} \mathrm{O}_{2}(44.5 \pm 11.0$ to $19.9 \pm 12.4 \mathrm{mmHg}, p<0.05)$, a further increase in venous oxygen extraction, and a threefold increase in systemic lactate levels $(p<0.05)$.

(Continued on next page)
\end{abstract}


(Continued from previous page)

Conclusions: Acute normotensive anemia (HES hemodilution) was associated with a subtle decrease in brain tissue $\mathrm{P}_{\mathrm{t}} \mathrm{O}_{2}$ without clear evidence of global tissue hypoperfusion. By contrast, acute hypotensive anemia (saline hemodilution) resulted in a profound decrease in both brain and muscle tissue $\mathrm{P}_{\mathrm{t}} \mathrm{O}_{2}$ and evidence of inadequate global perfusion (lactic acidosis). These data emphasize the importance of maintaining $\mathrm{CO}$ and MAP to ensure adequacy of vital organ oxygen delivery during acute anemia. Improved methods of assessing $\mathrm{P}_{\mathrm{t}} \mathrm{O}_{2}$ may provide an earlier warning signal of vital organ hypoperfusion.

Keywords: Hemodilution, Anemia, Mean arterial pressure, Cardiac output, Hypotension, Partial pressure of oxygen in tissue

\section{Background}

The optimal care of critically ill patients often involves management of multiple risk factors for inadequate organ perfusion, including hypotension and anemia. Assessment of the impact of hypotension and anemia in the perioperative period demonstrates that both factors are associated with serious adverse outcomes. Interoperative hypotension has been associated with increased brain $[1,2]$, heart [3-5], and kidney injury [3, 6, 7] and mortality [8-10]. These outcomes often depend on the magnitude and duration of hypotension; for example, a 40\% drop in mean arterial pressure (MAP) from baseline for more than $30 \mathrm{~min}$ has been associated with myocardial injury [5]. Perioperative and acute interoperative anemia have also been associated with similar patterns of adverse events; including evidence of brain $[11,12]$, heart $[13,14]$, and kidney injury $[15,16]$ and mortality [14, 16-18]. Experimental models of acute anemia suggest that inadequate microcirculatory perfusion and tissue hypoxia contribute as a mechanism of vital organ injury and mortality [19-21].

Additionally, current clinical practice often favors a restrictive fluid therapy and red blood cell $(\mathrm{RBC})$ transfusion approaches in surgical and critically ill patients. While many of the completed prospective randomized clinical trials favor the non-inferiority of a restrictive transfusion threshold near a hemoglobin concentration $(\mathrm{Hb})$ of $70-80 \mathrm{~g} / \mathrm{L}$ [22-24], more recent analysis of these data suggest that low $\mathrm{Hb}$ levels in the restrictive arms of these studies may be associated with increased organ injury and mortality in specific patient populations [25, 26].

We performed an experimental study to measure the partial pressure of oxygen in tissue $\left(\mathrm{P}_{\mathrm{t}} \mathrm{O}_{2}\right)$ in the brain and skeletal muscle, and other parameters of systemic perfusion, under conditions of acute normotensive vs. hypotensive hemodilutional anemia to assess the combined impact of acute anemia and hypotension on tissue perfusion. We hypothesize that optimal tissue perfusion depends on multiple interactive physiological parameters, including $\mathrm{Hb}$ and blood pressure, during acute blood loss and fluid resuscitation.

\section{Methods}

\section{Overview and preparation}

The Animal Care and Use Committee at St. Michael's hospital approved all animal protocols. Twenty-nine male Sprague-Dawley rats (Jackson laboratory) with a mean weight near $500 \mathrm{~g}$ were anesthetized with isoflurane $2-3 \%$ in $21 \%$ oxygen for the 
duration of the experiment. The trachea was intubated and the lungs were mechanically ventilated using a pressure controlled ventilator, with peak inspiratory pressure between 15 and $17 \mathrm{~cm} \mathrm{H}_{2} \mathrm{O}$ and a respiratory rate between 60 and 70 breaths per minute and no additional PEEP, to a target partial pressure of arterial carbon dioxide $\left(\mathrm{P}_{\mathrm{a}} \mathrm{CO}_{2}\right)$ near $40 \mathrm{mmHg}$ (Kent Scientific Corp., Torrington, CT 06790).

The tail artery and vein were cannulated to perform the hemodilution and to monitor MAP, arterial blood gases, and $\mathrm{Hb}$ by co-oximetry. A jugular venous catheter was inserted in a retrograde manner toward the right atrium to provide measurements of venous blood gases. Ventilation was monitored by arterial blood gases to maintain normoxia and normocapnia. Blood pressure, ECG, and body temperature were measured using a computerized data-acquisition system (PowerLab, ADInstruments Inc., Colorado Springs CO 80906). Rectal temperature was maintained between 35 and $36{ }^{\circ} \mathrm{C}$ using a heating plate. The partial pressure of oxygen in the tissue (brain, skeletal muscle) or $\mathrm{P}_{\mathrm{t}} \mathrm{O}_{2}$ was measured using oxygen-dependent quenching of phosphorescence as previously described [27] utilizing a novel microsensor G4 Oxyphor technology (PMOD1000 instrument, Oxygen Enterprises, Ltd., Philadelphia, PA 19104-1808).

\section{Hemodilution protocol}

After performing all of the procedures, baseline measurements were collected for $10 \mathrm{~min}$. Rats then underwent either "normotensive" hemodilution with 1:1 volume exchange of $40 \%$ estimated total blood volume $(30 \mathrm{ml} / \mathrm{kg}$ ) with either $6 \%$ hydroxyethyl starch (HES) 130/0.4 in 0.9\% sodium chloride (Voluven, $n=14$, Fresenius Kabi Canada, Mississauga ON L4W 4Y3), or "hypotensive" hemodilution with $0.9 \%$ sodium chloride (saline, $n=11$ ). During hemodilution, arterial blood was exchanged with HES or saline at a fixed rate over $10 \mathrm{~min}$, using the push-pull infusion pump (PHD2000, Harvard Apparatus Canada, St. Laurent, Quebec, H4S 1R9). Following hemodilution, physiologic parameters were continuously acquired during a 60-min recovery period. Brain and hind limb skeletal muscle tissue $\mathrm{P}_{\mathrm{t}} \mathrm{O}_{2}$ were recorded continuously. Arterial and venous blood gases and co-oximetry measurements were collected at baseline, immediately following hemodilution, and at 30 and $60 \mathrm{~min}$ following completion of hemodilution using a heparinized syringe. Samples were analyzed using a blood gas analyzer and co-oximeter (ABL 800, Radiometer Canada, London ON, N5V 4T7).

An additional four rats were placed in a sham control group and did not undergo hemodilution, to serve as a time-based negative control group.

\section{Cardiac output measurements}

These experiments included four rats per hemodilution group, which underwent cardiac output $(\mathrm{CO})$ measurements before and after hemodilution. Transthoracic echocardiography was performed in hemodiluted rats in the supine position at baseline and within 15 to $30 \mathrm{~min}$ following hemodilution utilizing a high-frequency ultrasound system (Vevo 2100, MS-250 transducer, Visualsonics, Toronto, ON). Two dimensional long-axis images of the left ventricle in parasternal long- and short-axis views with M-mode measurements at mid-papillary muscle level and linear dimensions were analyzed offline (Vevo 2100 software v. 1.3) using the standard leading edge to leading edge technique. $\mathrm{CO}$ was calculated as $\mathrm{SV} \times \mathrm{HR}$, where $\mathrm{SV}$ and $\mathrm{HR}$ are 
stroke volume and heart rate, respectively. SV and ejection fraction (EF) were measured using the Teicholz cubed formula, LV volume $=7 \times \mathrm{LVID}^{3} /(2.4+\mathrm{LVID})$, followed by the difference between ESV and EDV, where LVID, ESV, and EDV are left ventricular internal diameter, end systolic volume, and end diastolic volume, respectively. Fractional shortening (FS\%) was calculated as (LVIDd-LVIDs)/ LVIDd $\times 100$, where LVIDd and LVIDs are left ventricular end diastolic and end systolic internal diameters, respectively. Three consecutive cardiac cycles were averaged for all analyses.

\section{Statistical analysis}

All data are presented as mean \pm SD. Data were analyzed by repeated measures two-way ANOVA and post hoc Tukey test, where appropriate according to Sigmaplot software (SigmaStat 11.0).

\section{Results}

Baseline values were comparable for all parameters measured between the three experimental and control groups. No differences in heart rate $(299.0 \pm 29.5,309.7 \pm 51.8,290.5$ $\pm 3.2 \mathrm{bpm})$ or body temperature $\left(36.1 \pm 0.5,36.0 \pm 0.4,35.9 \pm 0.3{ }^{\circ} \mathrm{C}\right)$ were observed at baseline or at any time point for the HES, saline, and sham control groups, respectively. Arterial and venous blood gases and $\mathrm{Hb}$ concentrations are reported in Tables 1 and 2.

\section{Arterial and venous co-oximetry and blood gas analysis}

In the normotensive hemodilution (HES) group, mean $\mathrm{Hb}$ values decreased from a baseline of $131 \pm 9$ to $66 \pm 6 \mathrm{~g} / \mathrm{L}$ immediately following hemodilution $(p<0.001)$. In the hypotensive hemodilution saline group, $\mathrm{Hb}$ decreased from $130 \pm 11$ to $79 \pm 5 \mathrm{~g} / \mathrm{L}$ (Table $1 ; p<0.001)$. The $\mathrm{Hb}$ concentration in the saline hemodilution group was initially higher than in the HES hemodilution group (Table 1). In the sham control rats, $\mathrm{Hb}$ did not decrease over time.

Arterial oxygen tension $\left(\mathrm{P}_{\mathrm{a}} \mathrm{O}_{2}\right)$ and $\mathrm{Hb}$ saturation remained stable and did not decrease throughout the experimental protocol in any group (Tables 1 and 2, Fig. 1). Venous oxygen tension $\left(\mathrm{P}_{\mathrm{v}} \mathrm{O}_{2}\right)$ and saturation decreased from baseline after $60 \mathrm{~min}$ in all groups. There was no difference between $\mathrm{P}_{\mathrm{v}} \mathrm{O}_{2}$ between the sham controls and the HES hemodilution group. By contrast, there was a more profound decrease in $\mathrm{P}_{\mathrm{v}} \mathrm{O}_{2}$ and saturation in the saline hemodiluted group (Tables 1 and 2, Fig. $1, p<0.05$ ). Following saline hemodilution, the $\mathrm{P}_{\mathrm{a}} \mathrm{O} 2$ was increased transiently at $30 \mathrm{~min}$ following hemodilution. This change was associated with a reduction in $\mathrm{P}_{\mathrm{a}} \mathrm{CO}_{2}$ (Table 2; $p<0.001$ ), which is consistent with a respiratory compensation to metabolic acidosis. Animals in this group developed a lactic acidosis, as indicated by a significant increase in lactate, a reduction in $\mathrm{pH}$, and $\mathrm{HCO}_{3}^{-}$(Table 2, Fig. 1, $p<0.001$ for all). A maximal rise in arterial lactate was achieved by $60 \mathrm{~min}$ following hemodilution ( $3.5 \pm 1.3$ to $10.9 \pm 6.2 \mathrm{mmol} / \mathrm{L}, p<0.05)$.

\section{Mean arterial blood pressure measurements}

There was a significant treatment, time, and interaction effect (two-way ANOVA; $p<0.001$ for all). MAP was maintained for the duration of the 60-min recovery period in both the normotensive hemodilution and control group (Fig. 2). By contrast, there was 


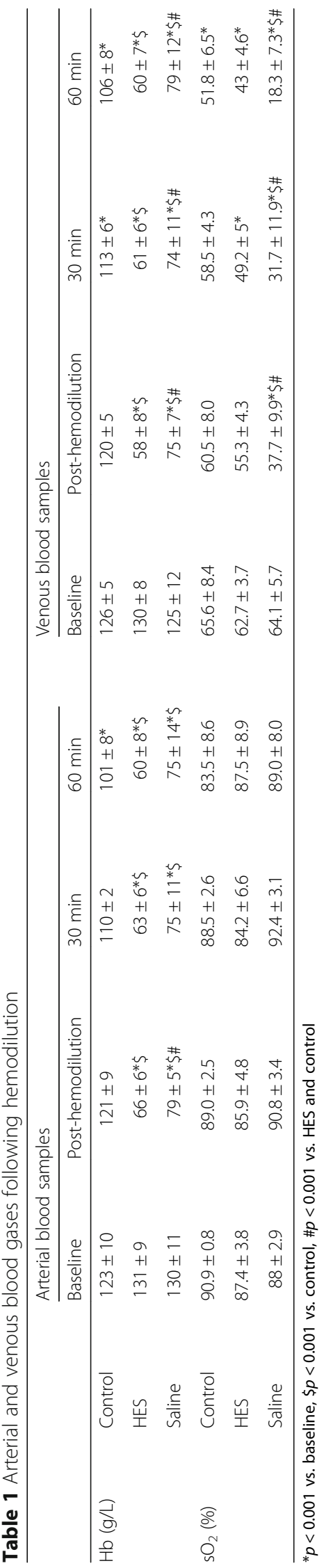




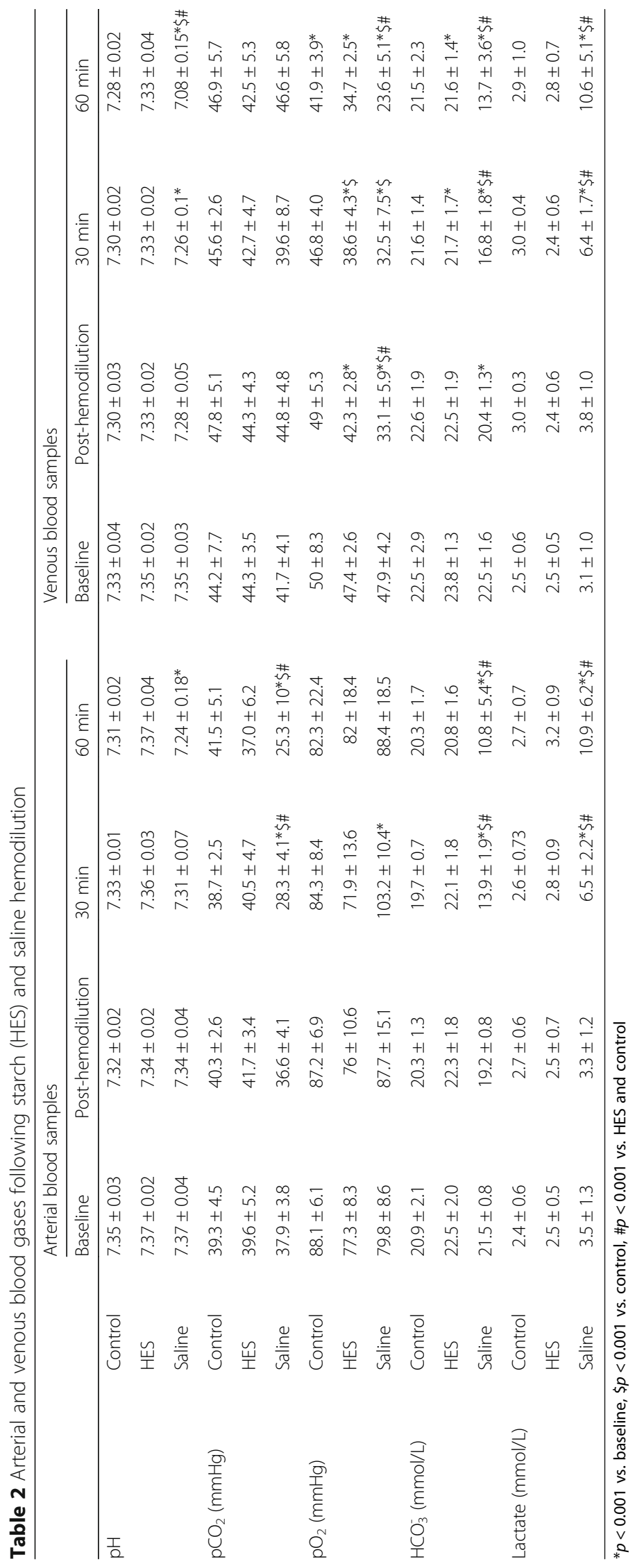



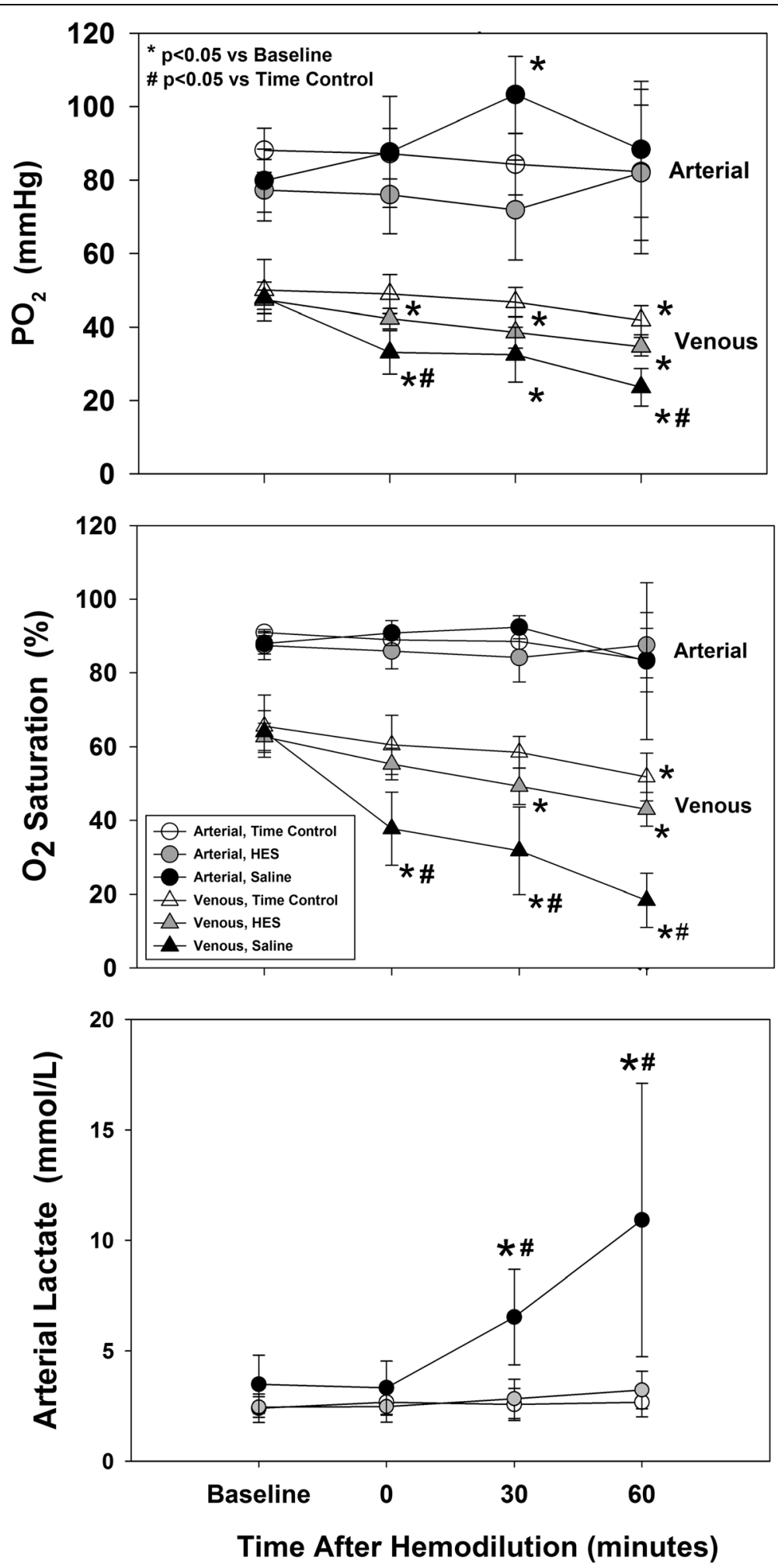

Fig. 1 (See legend on next page.) 
(See figure on previous page.)

Fig. 1 Upper panel Arterial $\mathrm{PO}_{2}$ remained stable except for a transient increase at 30 min (associated with hyperventilation) in the saline hemodilution group. A significant reduction in venous $\mathrm{PO}_{2}$ was observed in the saline hemodilution group relative to the controls $\left({ }^{*} p<0.001\right.$ vs. baseline, $\# p<0.05$ vs. control). Middle panel Arterial oxygen saturation remained stable in all groups. A significant reduction in venous $\mathrm{PO}_{2}$ was observed in all groups relative to baseline. The venous oxygen saturation in the saline hemodilution group was reduced relative to the controls and HES group ( ${ }^{*} p<0.001$ vs. baseline, $\# p<0.05$ vs. control and HES). Lower panel A significant rise in arterial lactate was only observed in the saline hemodilution group $\left({ }^{*} p<0.001\right.$ vs. baseline, $\# p<0.05$ vs. control and HES)

an immediate decrease in MAP following hemodilution in the saline hemodilution group (77.3 \pm 4.0 vs. $42.8 \pm 5.2 \mathrm{mmHg}, p<0.05$ ), which persisted to the 60 -min recovery period $(31.1 \pm 12.8 \mathrm{mmHg})$. MAP was significantly lower in the saline hemodilution group, relative to both controls and starch hemodilution groups at all post-hemodilution time points (Fig. 2, $p<0.001$ ).

\section{Partial pressure of oxygen in brain and muscle tissue $\left(\mathrm{P}_{\mathrm{t}} \mathrm{O}_{2}\right)$}

There was a significant time and interaction effect for brain $\mathrm{P}_{t} \mathrm{O}_{2}$ when comparing all three experimental groups (two-way ANOVA; $p<0.001$ for both). Brain $\mathrm{P}_{\mathrm{t}} \mathrm{O}_{2}$ remained stable in the time-based control sham hemodiluted group. Following normotensive hemodilution with HES, brain $\mathrm{P}_{\mathrm{t}} \mathrm{O}$ was reduced from a baseline value of $22.1 \pm 5.6 \mathrm{mmHg}$ to a value of $15.6 \pm 6.5 \mathrm{mmHg}$ immediately following hemodilution. The brain $\mathrm{P}_{\mathrm{t}} \mathrm{O}_{2}$ remained decreased for $60 \mathrm{~min}$ reaching a value of $17.5 \pm 4.4 \mathrm{mmHg}$ (Fig. 2, $p<0.05$ ). Rats undergoing hypotensive hemodilution with saline experienced a greater decrease in brain $\mathrm{P}_{\mathrm{t}} \mathrm{O}_{2}$ which decreased from baseline $(23.2 \pm 8.2 \mathrm{mmHg})$ to values as low as $16.0 \pm 4.5 \mathrm{mmHg}$ immediately following hemodilution. The brain $\mathrm{P}_{\mathrm{t}} \mathrm{O}_{2}$ reached a nadir value of $10.7 \pm 3.6 \mathrm{mmHg}$ after $60 \mathrm{~min}$ (Fig. $2, p<0.05$ ).

There was no time or interaction effect observed for hind limb skeletal muscle $\mathrm{PO}_{2}$ $(p=0.051$ and 0.082 , respectively). However, there was a significant time-treatment interaction (two-way ANOVA; $p<0.001$ ). No change in muscle $\mathrm{P}_{\mathrm{t}} \mathrm{O}_{2}$ was observed following sham procedure or HES hemodilution (Fig. 2). By contrast, muscle $\mathrm{PO}_{2}$ decreased significantly from baseline values of $44.5 \pm 11.0 \mathrm{mmHg}$ to $30.6 \pm 10.6 \mathrm{mmHg}$ immediately following hemodilution with saline (Fig. $2, p<0.05$ ). In this group, muscle $\mathrm{P}_{\mathrm{t}} \mathrm{O}_{2}$ reached a nadir at $60 \mathrm{~min}(19.9 \pm 12.4 \mathrm{mmHg}, p<0.05)$.

\section{Cardiac output measurements}

$\mathrm{CO}$ data from normotensive and hypotensive hemodilution groups are presented in Table 3. These experiments demonstrate that $\mathrm{CO}$ is increased in the normotensive HES hemodilution group, predominantly due to an increase in diastolic volume and stroke volume. These changes were not observed in the hypotensive saline hemodilution group which demonstrated a decrease in CO, SV, and diastolic volume (Table 3).

\section{Discussion}

We demonstrated a significant interaction between low $\mathrm{Hb}$ concentration and low MAP with respect to limiting tissue oxygen delivery in brain and muscle, in a model of normotensive vs. hypotensive hemodilution. During normotensive hemodilution with HES, blood pressure was maintained, $\mathrm{CO}$ increased, and systemic perfusion was 

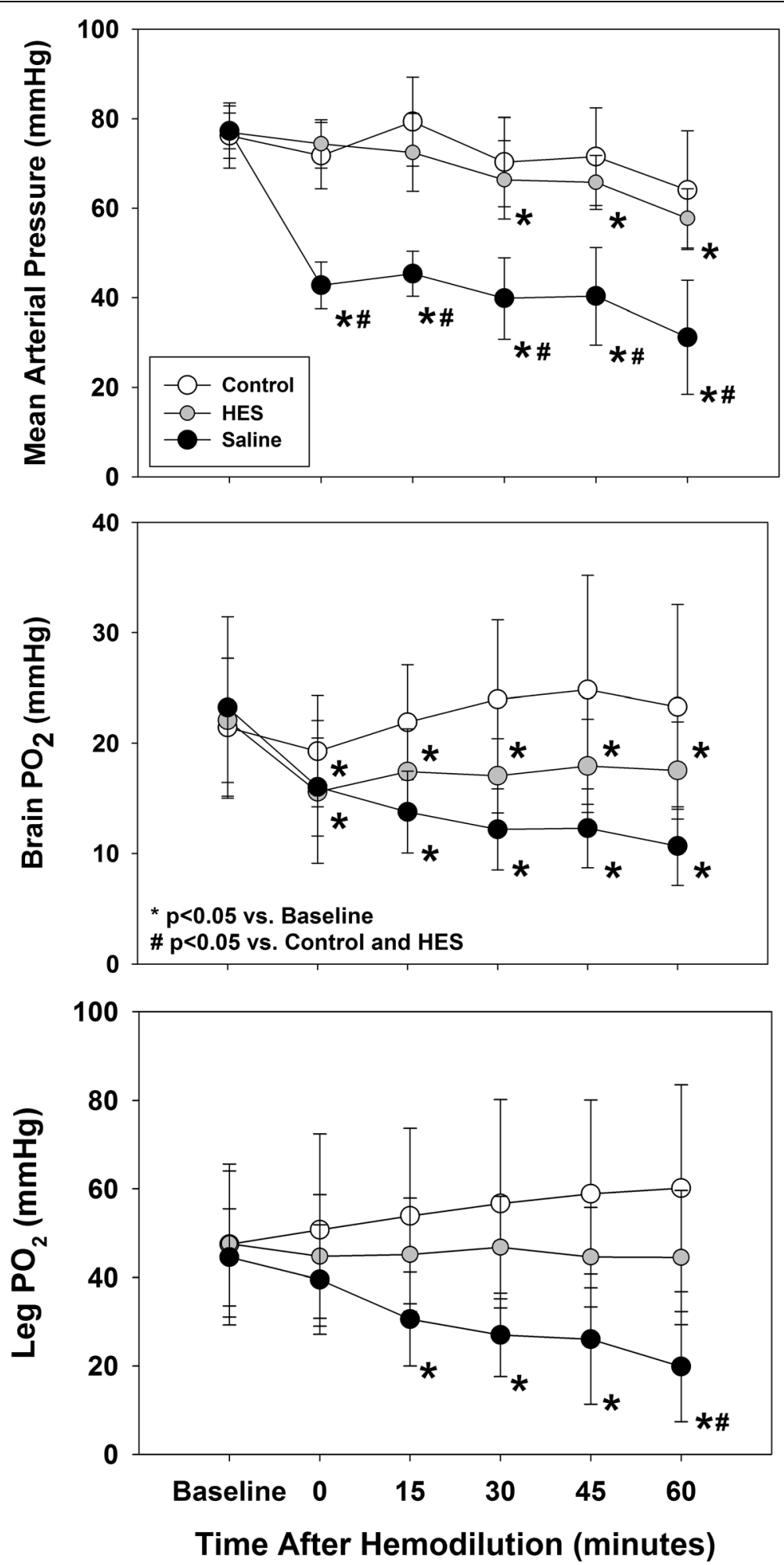

Fig. 2 (See legend on next page.) 
(See figure on previous page.)

Fig. 2 Upper panel Mean arterial pressure remained stable in controls and after hemodilution with hydroxyethyl starch (HES) but decreased significantly, relative to controls and HES hemodilution groups, following hemodilution with saline ( ${ }^{*} p<0.001$ vs. baseline, $\# p<0.05$ vs. control and HES). Middle panel Brain $\mathrm{PO}_{2}$ decreased from baseline following hemodilution with both HES and saline ( ${ }^{*} p<0.001$ vs. baseline). Lower panel Skeletal muscle $\mathrm{PO}_{2}$ remained stable in control and $\mathrm{HES}$ hemodilution groups but was reduced relative to baseline and controls after saline hemodilution ${ }^{*} p<0.001$ vs. baseline, $\# p<0.05$ vs. control and HES)

generally preserved, as indicated by the absence of lactic acidosis and sustained muscle $\mathrm{P}_{t} \mathrm{O}_{2}$. However, under these conditions, brain tissue $\mathrm{P}_{t} \mathrm{O}_{2}$ was significantly reduced, suggesting that tissue oxygen delivery did not meet the higher metabolic requirements for oxygen in the brain. These data are consistent with our previous studies, which demonstrate that acute normotensive anemia is associated with brain tissue hypoxia and activation of hypoxic cellular signaling pathways, including hypoxia inducible factor (HIF) [20]. This data may help to explain why acute hemodilution and anemia are associated with increased stroke incidence in patients undergoing cardiac and noncardiac surgery $[11,12]$. In addition, acute anemic conditions which produce mild brain tissue hypoxia have been associated with evidence of more severe renal tissue hypoxia $[21,28]$; providing a plausible explanation for both stroke acute kidney injury (AKI) in patient exposed to hemodilutional anemia $[12,16]$. The combined effect of inadequate perfusion to vital organs during acute anemia may contribute to the observed association of increased mortality in anemic perioperative patients $[16,17]$.

By contrast, hemodilution with saline resulted in hypotension, a reduction in $\mathrm{CO}$, a further reduction in brain $\mathrm{P}_{t} \mathrm{O}_{2}$, a newly observed reduction in muscle $\mathrm{P}_{t} \mathrm{O}_{2}$, and a

Table 3 ECHO measures following hemodilution

\begin{tabular}{llcc}
\hline & & Baseline & Post-hemodilution \\
\hline MAP $(\mathrm{mmHg})$ & HES & $82.2 \pm 19.6$ & $74.3 \pm 19.7$ \\
$\mathrm{Hb}(\mathrm{g} / \mathrm{L})$ & Saline & $103.6 \pm 12.6$ & $60.0 \pm 5^{*}$ \\
& HES & $144 \pm 6$ & $77 \pm 7^{*}$ \\
$\mathrm{CO}(\mathrm{mL} / \mathrm{min})$ & Saline & $136 \pm 3$ & $88 \pm 10^{*} \#$ \\
& HES & $57.7 \pm 8.7$ & $116.8 \pm 15.6^{*}$ \\
$\mathrm{HR}(\mathrm{bpm})$ & Saline & $72.8 \pm 22.4$ & $41.1 \pm 14.0^{*} \#$ \\
& HES & $323.6 \pm 46.1$ & $382.0 \pm 29.0$ \\
$\mathrm{SV}(\mu \mathrm{L})$ & Saline & $362.9 \pm 22.7$ & $333.0 \pm 23.0$ \\
& HES & $179.9 \pm 26.9$ & $305.7 \pm 32.2^{*}$ \\
Diastole volume $(\mu \mathrm{L})$ & Saline & $199.1 \pm 55.5$ & $122.1 \pm 33.8^{*} \#$ \\
& HES & $217.5 \pm 45.1$ & $331.8 \pm 30.8^{*}$ \\
Systole volume $(\mu \mathrm{L})$ & Saline & $263.5 \pm 70.2$ & $149.8 \pm 33.1^{*} \#$ \\
& HES & $37.6 \pm 21.9$ & $26.1 \pm 12.1$ \\
EF (\%) & Saline & $64.4 \pm 16.6$ & $27.7 \pm 11.2$ \\
FS (\%) & HES & $83.5 \pm 6.6$ & $92.1 \pm 3.6$ \\
& Saline & $75.3 \pm 2.8$ & $81.1 \pm 8.7$ \\
\hline
\end{tabular}

${ }^{*} p<0.01$ vs. baseline, $\# p<0.05$ vs HES; two-way ANOVA repeated measures 
severe increase in lactate suggestive of profound systemic ischemia. These data demonstrate the additive impact of combined low $\mathrm{Hb}$ in the face of a low $\mathrm{CO}$ and low MAP on tissue oxygen delivery in an experimental model. The mechanism likely involves inadequate fluid resuscitation with reduced intravascular volume and an inadequate cardiovascular response to anemia as indicated by the $\mathrm{CO}$ and diastolic volume analysis. From prior studies, we understand that during acute anemia, oxygen homeostasis is maintained by an active increase in $\mathrm{CO}$ to ensure perfusion of vital organs including the brain $[19,20]$. Inhibition of the CO response results in accentuation of tissue hypoxia [19]. We observed a similar effect in the saline hemodilution group where an inadequate $\mathrm{CO}$ response to anemia resulted in profound tissue hypoxia further demonstrating the need to preserve adequate intravascular fluid volume during anemia.

\section{Can measurement of tissue $\mathrm{PO}_{2}$ inform clinical practice to improve outcomes?}

Clinical monitoring of the partial pressure of oxygen in brain tissue has been performed directly using invasive tissue probes in patients exposed to neurotrauma; however, the invasive nature of these probes severely limits their use clinically. Indirect assessment of brain $\mathrm{P}_{\mathrm{t}} \mathrm{O}_{2}$ has been achieved utilizing near infrared spectroscopy (NIRS). NIRS measures changes in arterial and venous oxy- and deoxyhemoglobin levels which indirectly reflect levels of microvascular oxygenation. NIRS is capable of detecting cerebral microvascular oxygen desaturation in patients undergoing heart surgery [6, 29-31]. Treatment algorithms have been defined to respond to, and correct, episodes of cerebral desaturation $[29,31]$. While these maneuvers are able to correct the observed cerebral desaturations, only one study has demonstrated improvement in patient outcome [31].

Other novel light-based methods for directly measuring cellular energetics and tissue $\mathrm{PO}_{2}$ are being developed. Spectroscopic approaches, including broadband spectroscopy, allowed for measurement of the oxidative state of cellular cytochromes which reflect cellular energetics [32,33]. Measurement of cutaneous mitochondrial $\mathrm{PO}_{2}$, utilizing the oxygen-dependent delayed fluorescence of protopor-phyrin IX in the skin [34, 35], has been used to assess the mitochondrial $\mathrm{PO}_{2}$ response to acute hemodilution in an experimental pig model [35]. This approach was able to detect tissue hypoxia at an earlier stage of hemodilution relative to more traditional measurements including changes in MAP, serum lactate, $\mathrm{VO}_{2}$, and NIRS [35]. Future studies will be required to assess the impact of these technologies on patient outcomes.

In clinical studies, both hypotension [1-10] and anemia [11-18] have been independently associated with increase acute renal injury $[3,6,7,15,16]$, myocardial infarction $[3-5,13,14]$, stroke $[1,2,11,12]$, and mortality [8-10, 14, 16-18]. However, few of these retrospective analyses have formally assessed the combined impact of low $\mathrm{Hb}$ and low MAP on patient outcome. A 2012 post hoc analysis by Haase et al. demonstrated a 3.36 (1.34-8.41)-fold increase in cardiac surgery risk of AKI associated with a combination of anemia and hypotension during $\mathrm{CPB}$ relative to anemia alone [36]. However, a retrospective study by Sickeler et al. in 2014, which intended to replicate Haase's findings, involved a much larger cohort of 3963 patients and did not find any association between the cooccurrence of hypotension and anemia in cardiac surgery-related AKI risk [37]. Further clinical research is needed to fully assess the potential interaction between anemia and hypotension and their combined impact on patient outcome. 


\section{Optimal choice of resuscitation fluid in critical care}

Data to support the choice of optimal fluid for resuscitation (blood, colloid, crystalloid, blood substitute) in specific critical care settings is lacking [38]. While a complete review is beyond the scope of this manuscript, our data support some interesting observations about fluid restriction and the potential value of monitoring tissue $\mathrm{P}_{t} \mathrm{O}_{2}$ to assess fluid replacement and transfusion strategies. Recent assessment of clinical practice favors goal-directed and/or restrictive fluid management strategies [39]. In addition, review of management strategies in critical care demonstrate a preference toward crystalloid as the first choice for fluid therapy [40] and an overall increase in vasopressor use [41]. This combination of treatment strategies may lead to an increased risk of patients with reduced intravascular volume and support the priority of increased utilization of monitors which assess the adequacy of microvascular perfusion of vital organs [42].

Data from prospective randomized trials assessing restrictive vs. liberal RBC transfusion thresholds have largely favored a restrictive approach [43]. More recent analysis suggest that some patient populations may be harmed by this restrictive approach including patients undergoing cardiac surgery $[44,45]$ or those experiencing acute myocardial ischemia [25]. Data from the TITRe2 trial demonstrated that patients randomized to a restrictive transfusion threshold $(\mathrm{Hb}<7.5 \mathrm{~g} / \mathrm{dL})$ experienced a higher mortality [(4.2 vs. 2.6\%; HR 1.64 (1.00 to 2.679)], relative to patients randomized to a liberal threshold [44]. Early data from the TRICS trial in cardiac surgery also demonstrated a trend to increased adverse events including stroke (3 vs. 0 ) and death ( 4 vs. 1) in the restrictive study arm [46]. Utilization of methods to directly assess tissue oxygen delivery may help to define appropriate patient-specific fluid therapy and RBC transfusion thresholds in different patient populations. Finally, direct measurement of tissue oxygen delivery may promote the development of novel blood substitutes, including hemoglobin-based oxygen carriers (HBOCs). In experimental models, HBOCs have been demonstrated to maintain oxygen delivery to tissue during severe degrees of volume exchange [47]. However, due to concerns about toxicity and adverse clinical outcomes associated with HBOC use [48], future development of HBOCs will require measures of both efficacy $\left(\mathrm{P}_{\mathrm{t}} \mathrm{O}_{2}\right)$ and safety.

There are several limitations to the current study. We did not provide a whole blood exchange control, as these controls had been performed previously without any effect on tissue oxygen measurements relative to time-based controls [49]. We did not directly assess changes in intravascular volume. Further, although crystalloids and colloids are used clinically, they are typically not used comparably in a direct 1:1 blood volume exchange. Thus, our saline hemodilution group likely resulted in additional hemodynamic stress, including reduced intravascular volume that is not reflective of clinical care.

\section{Conclusions}

In this study, we observed that hypotensive anemia (1:1 saline/blood fluid exchange) resulted in global ischemia and severe tissue hypoxia. By contrast, normotensive anemia (1:1 HES/blood fluid exchange) preserved global organ perfusion but was unable to prevent a subtle reduction in brain tissue $\mathrm{P}_{\mathrm{t}} \mathrm{O}_{2}$. These data support the ongoing assessment of clinically applicable technologies to assess and measure tissue $\mathrm{P}_{t} \mathrm{O}_{2}$, in order to develop strategies maintaining tissue oxygen delivery and limiting adverse events associated with tissue hypoxia in patients with critical illness. 


\section{Abbreviations}

$\mathrm{Hb}$ : Hemoglobin; HES: Hydroxyethyl starch; MAP: Mean arterial pressure; $\mathrm{PCO}_{2}$ : Partial pressure of carbon dioxide; $\mathrm{PO}_{2}$ : Partial pressure of oxygen

\section{Funding}

This study was supported by the Children's Discovery Institute and St. Michael's Hospital AHSC AFP Innovation Fund. Dr. Hare and Dr. Mazer are supported by University of Toronto, Department of Anesthesia Merit Awards.

\section{Availability of data and materials}

The datasets supporting the conclusions of this article are included within the article and its additional files.

\section{Authors' contributions}

GMTH, CDM, AD, SR, DFW, and AKYT conceptualized the study and designed the protocol. AKYT, NM, TK, EL, and JFD performed the experiments. GMTH, CDM, TK, NM, and AKYT analyzed the data and performed the statistical analysis. GMTH, CDM, AD, TK, NM, SR, DFW, and KC wrote and edited the manuscript. All authors read and approved the final manuscript.

\section{Competing interests}

The authors declare that they have no competing interests.

\section{Ethics approval}

All animal protocols were approved by the Animal Care and Use Committee at St. Michael's Hospital.

\section{Author details}

${ }^{1}$ Department of Anesthesia, St. Michael's Hospital, 30 Bond Street, Toronto, Ontario M5B 1W8, Canada. ${ }^{2}$ Keenan Research Centre for Biomedical Science, Li Ka Shing Knowledge Institute, St. Michael's Hospital, 30 Bond Street, Toronto, Ontario M5B 1W8, Canada. ${ }^{3}$ Department of Physiology, University of Toronto, Toronto, Ontario M5S 1A8, Canada. ${ }^{4}$ Division of Pediatric Critical Care Medicine, Washington University in Saint Louis, Saint Louis, MO 63130, USA. ${ }^{5}$ Department of Biochemistry and Biophysics, Perelman School of Medicine, University of Pennsylvania, Philadelphia, PA 19104, USA. ${ }^{6}$ Department of Medicine, Division of Cardiology, St. Michael's Hospital, 30 Bond Street, Toronto, Ontario M5B 1W8, Canada.

Received: 9 September 2016 Accepted: 21 February 2017

Published online: 01 March 2017

\section{References}

1. Bijker JB, Persoon S, Peelen LM, Moons KG, Kalkman CJ, Kappelle LJ, van Klei WA (2012) Intraoperative hypotension and perioperative ischemic stroke after general surgery: a nested case-control study. Anesthesiology 116(3):658-664

2. Group PS, Devereaux PJ, Yang H, Yusuf S, Guyatt G, Leslie K, Villar JC, Xavier D, Chrolavicius S, Greenspan L et al (2008) Effects of extended-release metoprolol succinate in patients undergoing non-cardiac surgery (POISE trial): a randomised controlled trial. Lancet 371(9627):1839-1847

3. Walsh M, Devereaux PJ, Garg AX, Kurz A, Turan A, Rodseth RN, Cywinski J, Thabane L, Sessler DI (2013) Relationship between intraoperative mean arterial pressure and clinical outcomes after noncardiac surgery: toward an empirical definition of hypotension. Anesthesiology 119(3):507-515

4. Devereaux PJ, Sessler DI, Leslie K, Kurz A, Mrkobrada M, Alonso-Coello P, Villar JC, Sigamani A, Biccard BM, Meyhoff CS et al (2014) Clonidine in patients undergoing noncardiac surgery. N Engl J Med 370(16):1504-1513

5. van Waes JA, van Klei WA, Wijeysundera DN, van Wolfswinkel L, Lindsay TF, Beattie WS (2016) Association between intraoperative hypotension and myocardial injury after vascular surgery. Anesthesiology 124(1):35-44

6. Ono M, Arnaoutakis GJ, Fine DM, Brady K, Easley RB, Zheng Y, Brown C, Katz NM, Grams ME, Hogue CW (2013) Blood pressure excursions below the cerebral autoregulation threshold during cardiac surgery are associated with acute kidney injury. Crit Care Med 41(2):464-471

7. Sun LY, Wijeysundera DN, Tait GA, Beattie WS (2015) Association of intraoperative hypotension with acute kidney injury after elective noncardiac surgery. Anesthesiology 123(3):515-523

8. Bijker JB, van Klei WA, Vergouwe Y, Eleveld DJ, van Wolfswinkel L, Moons KG, Kalkman CJ (2009) Intraoperative hypotension and 1-year mortality after noncardiac surgery. Anesthesiology 111(6):1217-1226

9. Monk TG, Bronsert MR, Henderson WG, Mangione MP, Sum-Ping ST, Bentt DR, Nguyen JD, Richman JS, Meguid RA, Hammermeister KE (2015) Association between intraoperative hypotension and hypertension and 30-day postoperative mortality in noncardiac surgery. Anesthesiology 123(2):307-319

10. Sessler DI, Sigl JC, Kelley SD, Chamoun NG, Manberg PJ, Saager L, Kurz A, Greenwald S (2012) Hospital stay and mortality are increased in patients having a "triple low" of low blood pressure, low bispectral index, and low minimum alveolar concentration of volatile anesthesia. Anesthesiology 116(6):1195-1203

11. Ashes C, Judelman S, Wijeysundera DN, Tait G, Mazer CD, Hare GM, Beattie WS (2013) Selective beta1-antagonism with bisoprolol is associated with fewer postoperative strokes than atenolol or metoprolol: a single-center cohort study of 44,092 consecutive patients. Anesthesiology 119(4):777-787

12. Karkouti K, Djaiani G, Borger MA, Beattie WS, Fedorko L, Wijeysundera D, Ivanov J, Karski J (2005) Low hematocrit during cardiopulmonary bypass is associated with increased risk of perioperative stroke in cardiac surgery. Ann Thorac Surg 80(4):1381-1387

13. Beattie WS, Wijeysundera DN, Karkouti K, McCluskey S, Tait G, Mitsakakis N, Hare GM (2010) Acute surgical anemia influences the cardioprotective effects of beta-blockade: a single-center, propensity-matched cohort study. Anesthesiology 112(1):25-33 
14. Wu WC, Schifftner TL, Henderson WG, Eaton CB, Poses RM, Uttley G, Sharma SC, Vezeridis M, Khuri SF, Friedmann PD (2007) Preoperative hematocrit levels and postoperative outcomes in older patients undergoing noncardiac surgery. JAMA 297(22):2481-2488

15. Karkouti K, Beattie WS, Wijeysundera DN, Rao V, Chan C, Dattilo KM, Djaiani G, Ivanov J, Karski J, David TE (2005) Hemodilution during cardiopulmonary bypass is an independent risk factor for acute renal failure in adult cardiac surgery. J Thorac Cardiovasc Surg 129(2):391-400

16. Loor G, Li L, Sabik JF 3rd, Rajeswaran J, Blackstone EH, Koch C (2012) Nadir hematocrit during cardiopulmonary bypass: end-organ dysfunction and mortality. J Thorac Cardiovasc Surg 144(3):654-662.e654

17. Musallam KM, Tamim HM, Richards T, Spahn DR, Rosendaal FR, Habbal A, Khreiss M, Dahdaleh FS, Khavandi K, Sfeir PM et al (2011) Preoperative anaemia and postoperative outcomes in non-cardiac surgery: a retrospective cohort study. Lancet 378(9800):1396-1407

18. Carson JL, Poses RM, Spence RK, Bonavita G (1988) Severity of anaemia and operative mortality and morbidity. Lancet 1(8588):727-729

19. Hu T, Beattie WS, Mazer CD, Leong-Poi H, Fujii H, Wilson DF, Tsui AK, Liu E, Muhammad M, Baker AJ et al (2013) Treatment with a highly selective beta(1) antagonist causes dose-dependent impairment of cerebral perfusion after hemodilution in rats. Anesth Analg 116(3):649-662

20. Tsui AK, Marsden PA, Mazer CD, Adamson SL, Henkelman RM, Ho JJ, Wilson DF, Heximer SP, Connelly KA, Bolz SS et al (2011) Priming of hypoxia-inducible factor by neuronal nitric oxide synthase is essential for adaptive responses to severe anemia. Proc Natl Acad Sci U S A 108(42):17544-17549

21. Tsui AK, Marsden PA, Mazer CD, Sled JG, Lee KM, Henkelman RM, Cahill LS, Zhou YQ, Chan N, Liu E et al (2014) Differential HIF and NOS responses to acute anemia: defining organ-specific hemoglobin thresholds for tissue hypoxia. Am J Physiol Regul Integr Comp Physiol 307(1):R13-R25

22. Carson JL, Terrin ML, Noveck H, Sanders DW, Chaitman BR, Rhoads GG, Nemo G, Dragert K, Beaupre L, Hildebrand K et al (2011) Liberal or restrictive transfusion in high-risk patients after hip surgery. N Engl J Med 365(26):2453-2462

23. Hajjar LA, Vincent JL, Galas FR, Nakamura RE, Silva CM, Santos MH, Fukushima J, Kalil Filho R, Sierra DB, Lopes NH et al (2010) Transfusion requirements after cardiac surgery: the TRACS randomized controlled trial. JAMA 304(14):1559-1567

24. Hebert PC, Wells G, Blajchman MA, Marshall J, Martin C, Pagliarello G, Tweeddale M, Schweitzer I, Yetisir E (1999) A multicenter, randomized, controlled clinical trial of transfusion requirements in critical care. Transfusion Requirements in Critical Care Investigators, Canadian Critical Care Trials Group. N Engl J Med 340(6):409-417

25. Carson JL, Brooks MM, Abbott JD, Chaitman B, Kelsey SF, Triulzi DJ, Srinivas V, Menegus MA, Marroquin OC, Rao SV et al (2013) Liberal versus restrictive transfusion thresholds for patients with symptomatic coronary artery disease. Am Heart J 165(6):964-971.e961

26. Hovaguimian F, Myles PS (2016) Restrictive versus liberal transfusion strategy in the perioperative and acute care settings: a context-specific systematic review and meta-analysis of randomized controlled trials. Anesthesiology 125(1):46-61

27. Yu J, Ramadeen A, Tsui AK, Hu X, Zou L, Wilson DF, Esipova TV, Vinogradov SA, Leong-Poi H, Zamiri N et al (2013) Quantitative assessment of brain microvascular and tissue oxygenation during cardiac arrest and resuscitation in pigs. Anaesthesia 68(7):723-735

28. van Bommel J, Siegemund M, Henny C, Ince C (2008) Heart, kidney, and intestine have different tolerances for anemia. Transl Res 151(2):110-117

29. Deschamps A, Hall R, Grocott H, Mazer CD, Choi PT, Turgeon AF, de Medicis E, Bussieres JS, Hudson C, Syed S et al (2016) Cerebral oximetry monitoring to maintain normal cerebral oxygen saturation during high-risk cardiac surgery: a randomized controlled feasibility trial. Anesthesiology 124(4):826-836

30. Subramanian B, Nyman C, Fritock M, Klinger RY, Sniecinski R, Roman P, Huffmyer J, Parish M, Yenokyan G, Hogue CW (2016) A multicenter pilot study assessing regional cerebral oxygen desaturation frequency during cardiopulmonary bypass and responsiveness to an intervention algorithm. Anesth Analg 122(6):1786-1793

31. Murkin JM, Adams SJ, Novick RJ, Quantz M, Bainbridge D, Iglesias I, Cleland A, Schaefer B, Irwin B, Fox S (2007) Monitoring brain oxygen saturation during coronary bypass surgery: a randomized, prospective study. Anesth Analg 104(1):51-58

32. Kolyva C, Ghosh A, Tachtsidis I, Highton D, Smith M, Elwell CE (2013) Dependence on NIRS source-detector spacing of cytochrome c oxidase response to hypoxia and hypercapnia in the adult brain. Adv Exp Med Biol 789:353-359

33. Yeganeh HZ, Toronov V, Elliott JT, Diop M, Lee TY, St Lawrence K (2012) Broadband continuous-wave technique to measure baseline values and changes in the tissue chromophore concentrations. Biomed Opt Express 3(11):2761-2770

34. Harms F, Stolker RJ, Mik E (2016) Cutaneous respirometry as novel technique to monitor mitochondrial function: a feasibility study in healthy volunteers. PLoS One 11(7):e0159544

35. Romers LH, Bakker C, Dollee N, Hoeks SE, Lima A, Raat NJ, Johannes T, Stolker RJ, Mik EG (2016) Cutaneous mitochondrial PO2, but not tissue oxygen saturation, is an early indicator of the physiologic limit of hemodilution in the Pig. Anesthesiology 125(1):124-132

36. Haase M, Bellomo R, Story D, Letis A, Klemz K, Matalanis G, Seevanayagam S, Dragun D, Seeliger E, Mertens PR et al (2012) Effect of mean arterial pressure, haemoglobin and blood transfusion during cardiopulmonary bypass on post-operative acute kidney injury. Nephrol Dial Transplant 27(1):153-160

37. Sickeler R, Phillips-Bute B, Kertai MD, Schroder J, Mathew JP, Swaminathan M, Stafford-Smith M (2014) The risk of acute kidney injury with co-occurrence of anemia and hypotension during cardiopulmonary bypass relative to anemia alone. Ann Thorac Surg 97(3):865-871

38. Orbegozo Cortes D, Gamarano Barros T, Njimi H, Vincent JL (2015) Crystalloids versus colloids: exploring differences in fluid requirements by systematic review and meta-regression. Anesth Analg 120(2):389-402

39. Corcoran T, Rhodes JE, Clarke S, Myles PS, Ho KM (2012) Perioperative fluid management strategies in major surgery: a stratified meta-analysis. Anesth Analg 114(3):640-651

40. Miller TE, Bunke M, Nisbet P, Brudney CS (2016) Fluid resuscitation practice patterns in intensive care units of the USA: a cross-sectional survey of critical care physicians. Perioper Med (London) 5:15 
41. Thongprayoon C, Cheungpasitporn W, Harrison AM, Carrera P, Srivali N, Kittamongkolchai W, Erdogan A, Kashani KB (2016) Temporal trends in the utilization of vasopressors in intensive care units: an epidemiologic study. BMC Pharmacol Toxicol 17(1):19

42. Mayer K, Trzeciak S, Puri NK (2016) Assessment of the adequacy of oxygen delivery. Curr Opin Crit Care 22(5):437-443

43. Carson JL, Carless PA, Hebert PC (2013) Outcomes using lower vs higher hemoglobin thresholds for red blood cell transfusion. JAMA 309(1):83-84

44. Murphy GJ, Pike K, Rogers CA, Wordsworth S, Stokes EA, Angelini GD, Reeves BC (2015) Liberal or restrictive transfusion after cardiac surgery. N Engl J Med 372(11):997-1008

45. Docherty AB, O'Donnell R, Brunskill S, Trivella M, Doree C, Holst L, Parker M, Gregersen M, Pinheiro de Almeida J, Walsh TS et al (2016) Effect of restrictive versus liberal transfusion strategies on outcomes in patients with cardiovascular disease in a non-cardiac surgery setting: systematic review and meta-analysis. BMJ 352:11351

46. Shehata N, Burns LA, Nathan H, Hebert P, Hare GM, Fergusson D, Mazer CD (2012) A randomized controlled pilot study of adherence to transfusion strategies in cardiac surgery. Transfusion 52(1):91-99

47. Hare GM, Liu E, Baker AJ, Mazer CD (2009) Effect of oxygen affinity on systemic perfusion and brain tissue oxygen tension after extreme hemodilution with hemoglobin-starch conjugates in rats. Intensive Care Med 35(11):1925-1933

48. Natanson C, Kern SJ, Lurie P, Banks SM, Wolfe SM (2008) Cell-free hemoglobin-based blood substitutes and risk of myocardial infarction and death: a meta-analysis. JAMA 299(19):2304-2312

49. McLaren AT, Marsden PA, Mazer CD, Baker AJ, Stewart DJ, Tsui AK, Li X, Yucel Y, Robb M, Boyd SR et al (2007) Increased expression of HIF-1alpha, nNOS, and VEGF in the cerebral cortex of anemic rats. Am J Physiol Regul Integr Comp Physiol 292(1):R403-R414

Submit your manuscript to a SpringerOpen ${ }^{\circ}$ journal and benefit from:

- Convenient online submission

- Rigorous peer review

- Immediate publication on acceptance

- Open access: articles freely available online

- High visibility within the field

- Retaining the copyright to your article 